\title{
Investigation of Subcategories according to the Level of Job Stress in Medical Technologist
}

\author{
Jung-Kyu So ${ }^{1}$, Jung-Suk Kim², Young-Hee Lee ${ }^{3}$, Dae-Jung Kim ${ }^{4}$, Chang-Eun Park ${ }^{5}$ \\ ${ }^{1}$ Department of Laboratory Medicine, St. Vincent Hospital, The Catholic University of Korea, Suwon, Korea \\ ${ }^{2}$ College of Nursing, Ajou University, Suwon, Korea \\ Department of Nursing, Dongnam Health University, Suwon, Korea \\ ${ }^{4}$ Department of Laboratory Medicine, Bundang Jesaeng Hospital, Seongnam, Korea \\ ${ }^{5}$ Department of Biomedical Laboratory Science, Molecular Diagnostics Research Institute, Namseoul University, Cheonan, Korea
}

\section{임상병리사의 직무스트레스의 수준에 따른 하위영역의 실태조사}

\author{
소정규 ${ }^{1}$, 김정숙 ${ }^{2}$, 이영희 ${ }^{3}$, 김대중 $^{4}$, 박창은 $^{5}$ \\ ${ }^{1}$ 가톨릭대학교 성빈센트병원 진단검사의학과, ${ }^{2}$ 아주대학교 간호대학, ${ }^{3}$ 동남보건대학교 간호학과, \\ ${ }^{4}$ 분당제생병원 진단검사의학과, ${ }^{5}$ 남서울대학교 임상병리학과 분자진단연구소
}

\begin{abstract}
The purpose of this study was to provide fundamental data for the plans to reduce occupational stress by analyzing occupational stress of medical technologist. The experimental group comprised of 193 medical technologists working in Gyeonggi province. Occupational stress was 49.74 out of 100. In detail, job insecurity showed a high value of 64.42 , followed by organizational system, lack of reward, physical environment, job demand, insufficient job control, interpersonal conflict, and occupational climate with respective values of 52.46, 52.30, 51.18, 49.57, 48.43, 39.78 and 39.77. It is recommended that those in high-stress job group increase physical activity and reduce job insecurity to improve health. The development of programs to reduce occupational stress are necessary, and this study can provide objective information using biological indicators.
\end{abstract}

Key words: Medical technologist, Organizations, Reward, Stress

This is an Open Access article distributed under the terms of the Creative Commons Attribution Non-Commercial License (http://creativecommons.org/licenses/by-nc/4.0) which permits unrestricted non-commercial use, distribution, and reproduction in any medium, provided the original work is properly cited.

Copyright ( 2017 The Korean Society for Clinical Laboratory Science. All rights reserved.
Corresponding author: Chang-Eun Park

Department of Biomedical Laboratory Science, Molecular Diagnostics Research Institute, Namseoul University, 91 Daehak-ro,

Seonghwan-eup, Seobuk-gu, Cheonan 31020 , Korea

Tel: 82-41-580-2722

Fax: 82-41-580-2932

E-mail: eun2777@hanmail.net

Received: January 31, 2017 Revised $1^{\text {st. }}$ : February 16, 2017

Revised $2^{\text {nd. }}$ : February 17, 2017

Revised $3^{\text {rd. }}$ February 18, 2017 Accepted: February 19, 2017

\section{INTRODUCTION}

Job stress has an effect on a person's well-being, which includes cognitive, psychological, physiological, and behavioral aspects. According to the US National Institute for Occupational Safety and Health [1,2], job stress can be defined as the harmful physical and emotional responses that occur when the requirements of a job do not match the capabilities, resources, or needs of a worker. Healthcare workers in hospitals are exposed to high levels of occupational stress resulting from heavy workload, extended working hours and high levels of time pressure. Hospital staff members, including physicians and nurses, have higher risk of suffering from depressive disorders compared to the general population [3]. Higher levels of workplace stress are associated with higher levels of depression and anxiety, as well as lower levels of resiliency, job satisfaction, and healthy lifestyle beliefs. This suggests development of intervention programs that focus on education and skills-building in health 
promoting behaviors, including emotional regulation of stress, anxiety and depression [4].

In terms of workplace type, half-day shift did not cause any significant change of fixed biorhythm in nurses. Cortisol and NK cell activity levels were low during night shift, suggesting that night shift itself involved high stress level, which is prejudicial to biodefense [5]. Accumulated job stress is a mechanism that increases the risk of health status by losing the balance of autonomic nervous system, immune function, and endocrine function. Most studies are limited to exploring correlation of job stress and ignore the affecting factors. The results of this study can help hospital managers develop solutions to job stress of medical technologists (also called medical laboratory technologist, medical laboratory scientist, clinical laboratory technologist, or clinical laboratory scientist). Increased workload among clinical laboratory scientists, growing job stress and declining job satisfaction are major concerns of laboratory managers and unit educators. This study examined the association of job stress of medical technologists.

\section{MATERIALS AND METHODS}

\section{Study design}

This is a descriptive correlation study attempting to grasp the level of job stress among medical technologists and to verify predictor variables of incidents.

\section{Sample and setting}

Data were collected by administering an internet questionnaire via visit from May to July 2014. This study was approved by the institutional review board of University (140428-2). The purpose of this study was explained to subjects during the visit, and the questionnaire was administered after obtaining their consent. All subjects agreed to participate in this study and responded to the survey questionnaire in Gyeonggi province medical technologists. A total of 193 subjects, excluding one subject with an inadequate response, were ultimately included in this investigation. Number of participants was calculated using G-Power 3.1.3, which is a program that estimates sample size. Minimum sample size required was calculated in unit of person, with significance level of 0.05 , effect size of 0.10 , and power of 0.8 for 28 independent variables. The questionnaire consisted of questions assessing general characteristics, job stress.

\section{Job stress}

Job stress was measured using short form of the Korean Occupational Stress Scale (SF-KOSS) developed by Chang et al [6], including the "physical environment" sphere for KOSS. This tool included 8 subcategories and 43 question items: Physical environment $(\mathrm{N}=3)$, job demand $(\mathrm{N}=8)$, insufficient job control $(\mathrm{N}=5)$, interpersonal conflict $(\mathrm{N}=4)$, job insecurity $(\mathrm{N}=6)$, organizational system $(\mathrm{N}=7)$, lack of reward $(\mathrm{N}=6)$, and occupational climate $(\mathrm{N}=4)$.

For each item, job stress was measured on a four-point Likert scale: Strongly disagree (1), disagree (2), agree (3), and strongly agree (4) with inverse conversion for positive items. Job stress points were calculated by converting them into 100-point marks by subarea, where higher scores indicate greater job stress. Cronbach's $\alpha$ of SF-KOSS was 0.633 in this study.

Score of subcategory=(actual score - number of questions) $\times 100$ /predicted top score possible - number of questions

Total score of job stress=total amount of independent 8 subcategories/8

\section{Data analysis}

Frequency, percentage, mean, standard deviation, median and range were used to reveal general characteristics and job stress. Data were analyzed using SPSS Statistics 18. General characteristics, job stress of the subjects were analyzed with descriptive statistics including frequency, percentage, mean, standard deviation, etc. To determine the correlation among general characteristics of the subjects, the ANOVA was performed. levels of job stress were analyzed by differences in general characteristics of the subjects using the Scheffe test or post hoc 
comparison. and the distribution of sub-categories according to job stress level (low, middle, high) was examined. Reliability of the tool was analyzed by Cronbach's $\alpha$ with significance level of 0.05 . The correlation between job stress was analyzed using Pearson correlation coefficients.

\section{RESULTS}

\section{General characteristics of subjects}

General characteristics of the subjects are shown in Table 1. Mean age of 193 subjects was 35.3 years old. One hundred thirty-six subjects (71.5\%) were over age of 30 years, and 101 subjects (52.3\%) were women. Among the subjects, 37.3\% had religion. For clinical experience, most

Table 1. General characteristics of the study participants ( $N=193)$

\begin{tabular}{|c|c|c|c|}
\hline Characteristics & Categories & N & $\%$ \\
\hline \multirow[t]{8}{*}{ Age } & mean $\pm S D \quad 35.28 \pm 8.13$ & & \\
\hline & $20 \sim 24$ & 11 & 5.7 \\
\hline & $25 \sim 29$ & 46 & 23.8 \\
\hline & $30 \sim 34$ & 36 & 18.7 \\
\hline & $35 \sim 39$ & 36 & 18.7 \\
\hline & $40 \sim 44$ & 38 & 19.7 \\
\hline & $45 \sim 49$ & 15 & 7.8 \\
\hline & $>50$ & 11 & 5.7 \\
\hline \multirow[t]{2}{*}{ Gender } & Male & 92 & 47.7 \\
\hline & Female & 101 & 52.3 \\
\hline \multirow{2}{*}{ Religion } & Yes & 72 & 37.3 \\
\hline & No & 121 & 62.7 \\
\hline \multirow[t]{13}{*}{ Work unit } & Collection & 23 & 11.9 \\
\hline & Hematology & 15 & 7.8 \\
\hline & Chemistry & 38 & 19.7 \\
\hline & Microbiology & 21 & 10.9 \\
\hline & Immunology & 26 & 13.5 \\
\hline & Pathology & 23 & 11.9 \\
\hline & Molecular diagnostic & 9 & 4.7 \\
\hline & Blood bank & 18 & 9.3 \\
\hline & Cardiovascular & 4 & 2.1 \\
\hline & Neuromuscular & 5 & 2.6 \\
\hline & Health management & 3 & 1.6 \\
\hline & General physiology & 2 & 1.0 \\
\hline & Others (included infection) & 6 & 3.1 \\
\hline \multirow[t]{3}{*}{ Educational level } & College & 107 & 55.4 \\
\hline & University & 64 & 33.2 \\
\hline & $>$ Graduate school & 22 & 11.4 \\
\hline \multirow[t]{3}{*}{ Type of work } & Full time & 164 & 85.0 \\
\hline & 3 shift & 6 & 3.1 \\
\hline & Other (only night) & 23 & 11.9 \\
\hline \multirow{4}{*}{$\begin{array}{l}\text { Average of night } \\
\text { work days } \\
\text { per month }\end{array}$} & $2.29 \pm 1.24$ & & \\
\hline & $1 \sim 2$ & 149 & 77.2 \\
\hline & $3 \sim 4$ & 19 & 9.8 \\
\hline & $>5$ & 25 & 13.0 \\
\hline
\end{tabular}

of the subjects (51.8\%) had over 10 years of experience. With regards to position, most of the subjects were registered general clinical laboratory scientists (63.2\%), with $85 \%$ working full-time. For type of institution, most of the subjects $(56.0 \%)$ worked at a general hospital. One hundred and five subjects (54.4\%) had occasional fatigue.

\section{Scores for job stress}

Mean score for job stress was $49.74 \pm 5.05$ points with a minimum of 36.07 points and a maximum of 71.58 points. Looking at mean scores of 8 subcategories of subordinate factors of occupational stress, score for high job insecurity was $64.42 \pm 12.06$ points, $52.46 \pm 15.20$ points for organizational system, $52.30 \pm 11.95$ points for lack of reward, $49.57 \pm 12.34$ points for job demand, $48.43 \pm 11.93$ points for insufficient job control, and 39.77 \pm 16.01 point for low occupational climate (Table 2).

Table 1. Continued

\begin{tabular}{|c|c|c|c|}
\hline Characteristic & Categories & N & $\%$ \\
\hline \multirow{2}{*}{$\begin{array}{l}\text { Special certificate } \\
\text { board (domestic) }\end{array}$} & Yes & 75 & 38.9 \\
\hline & No & 118 & 61.1 \\
\hline \multirow{5}{*}{$\begin{array}{l}\text { Type of work } \\
\text { institution } \\
\text { (No. of beds) }\end{array}$} & $<100$ & 3 & 1.6 \\
\hline & $100 \sim 200$ & 6 & 3.1 \\
\hline & General hospital & 108 & 56.0 \\
\hline & University hospital & 74 & 38.3 \\
\hline & Clinical laboratory center & 2 & 1.0 \\
\hline \multirow[t]{4}{*}{ Drinking } & None & 19 & 9.8 \\
\hline & $<1$ per month & 50 & 25.9 \\
\hline & $>1$ per month & 73 & 37.8 \\
\hline & $>1$ per week & 51 & 26.4 \\
\hline \multirow[t]{4}{*}{ Smoking } & Daily & 32 & 16.6 \\
\hline & Frequently & 10 & 5.2 \\
\hline & Quit smoking & 21 & 10.9 \\
\hline & None & 130 & 67.3 \\
\hline \multirow{4}{*}{ Snack } & None & 8 & 4.1 \\
\hline & Sometimes & 124 & 64.2 \\
\hline & Frequently & 55 & 28.5 \\
\hline & Very often & 6 & 3.1 \\
\hline \multirow[t]{2}{*}{ Previous disease } & Yes & 40 & 20.7 \\
\hline & No & 153 & 79.3 \\
\hline \multirow{2}{*}{$\begin{array}{l}\text { Previous therapy } \\
\text { for disease }\end{array}$} & Yes & 42 & 21.8 \\
\hline & No & 151 & 78.2 \\
\hline \multirow[t]{2}{*}{ Chronic disease } & Yes & 31 & 16.1 \\
\hline & No & 162 & 83.9 \\
\hline \multirow[t]{2}{*}{ Existing drug } & Yes & 20 & 10.4 \\
\hline & No & 173 & 89.6 \\
\hline \multirow[t]{4}{*}{ Fatigue } & None & 6 & 3.1 \\
\hline & Sometimes & 105 & 54.4 \\
\hline & Oftens & 63 & 32.6 \\
\hline & Always & 19 & 9.8 \\
\hline
\end{tabular}


Table 2. Mean score of job stress subcategories factors $(\mathrm{N}=193)$

\begin{tabular}{lc}
\hline \multicolumn{1}{c}{ Categories } & Mean \pm SD \\
\hline Total & $49.74 \pm 5.05$ \\
Physical environment & $51.18 \pm 13.19$ \\
Job demand & $49.57 \pm 12.34$ \\
Insufficient job control & $48.43 \pm 11.93$ \\
Interpersonal conflict & $39.78 \pm 9.33$ \\
Job insecurity & $64.42 \pm 12.06$ \\
Organizational system & $52.46 \pm 15.20$ \\
Lack of reward & $52.30 \pm 11.95$ \\
Occupational climate & $39.77 \pm 16.01$ \\
\hline
\end{tabular}

\section{Job stress according to third percentile}

Table 3 shows mean score for job stress according to three-one percentile distributed groups. These three group had low, medium and high job stress scores. These job score were 44.44, 49.70 and 55.06, respectively. The results of the survey indicated a statistically significant difference among the three groups ( $\mathrm{F}=263.053, p<0.001$ ). Whereas there were no significant differences in occupational climate, significant differences were found in physical environment, job demand and insufficient job control. High-stress group was higher than other groups

Table 3. Mean score for job stress according to third percentile $(\mathrm{N}=193)$

\begin{tabular}{|c|c|c|c|c|c|}
\hline Variable & $\begin{array}{c}\text { Low }^{\dagger}(\mathrm{N}=64) \\
\text { Mean } \pm \mathrm{SD}\end{array}$ & $\begin{array}{c}\text { Middle }^{\dagger}(\mathrm{N}=65) \\
\text { Mean } \pm \mathrm{SD}\end{array}$ & $\begin{array}{l}\text { High }^{\S}(\mathrm{N}=64) \\
\text { Mean } \pm \mathrm{SD}\end{array}$ & $\mathrm{F}(p)$ & Schéffe \\
\hline Total & $44.44 \pm 2.82$ & $49.70 \pm 1.02$ & $55.06 \pm 3.41$ & $263.053(0.000)$ & $\dagger<\neq<\S$ \\
\hline Physical environment & $44.44 \pm 11.88$ & $50.09 \pm 10.04$ & $59.03 \pm 13.41$ & $24.664(0.000)$ & $\dagger<\S, \neq<\S$ \\
\hline Job demand & $44.60 \pm 9.64$ & $48.40 \pm 10.97$ & $55.73 \pm 13.64$ & $15.413(0.000)$ & $\dagger<\S, \neq<\S$ \\
\hline Insufficient job control & $42.40 \pm 10.78$ & $48.31 \pm 9.72$ & $54.58 \pm 12.16$ & $19.906(0.000)$ & $\dagger<\S, \neq<\S$ \\
\hline Interpersonal conflict & $35.33 \pm 9.36$ & $40.77 \pm 8.41$ & $43.23 \pm 8.60$ & $13.524(0.000)$ & $\dagger<\neq, \dagger<\S$ \\
\hline Job insecurity & $59.38 \pm 11.74$ & $65.38 \pm 10.02$ & $68.49 \pm 12.73$ & $10.321(0.000)$ & $\dagger<\S$ \\
\hline Organizational system & $45.16 \pm 14.52$ & $52.60 \pm 13.35$ & $59.60 \pm 14.50$ & $16.703(0.000)$ & $\dagger<\neq<\S$ \\
\hline Lack of reward & $46.61 \pm 11.82$ & $53.00 \pm 9.58$ & $57.29 \pm 12.08$ & $14.708(0.000)$ & $\dagger<\neq, \quad \dagger<\S$ \\
\hline Occupational climate & $37.63 \pm 15.78$ & $39.10 \pm 13.58$ & $42.58 \pm 18.31$ & $1.615(0.202)$ & \\
\hline
\end{tabular}

Possible range $=1 \sim 100$.

Table 4. Job stress according to general characteristic ( $N=193)$

\begin{tabular}{|c|c|c|c|c|c|}
\hline \multirow{2}{*}{ Characteristics } & \multirow{2}{*}{ Categories } & \multicolumn{4}{|c|}{ Job stress } \\
\hline & & Mean \pm SD & $\mathrm{F}$ & $p$ & Scheffe \\
\hline \multirow[t]{7}{*}{ Age } & $20 \sim 24^{\dagger}$ & $51.89 \pm 5.21$ & 3.170 & 0.006 & $\|>* *$ \\
\hline & $25 \sim 29^{\ddagger}$ & $50.55 \pm 4.11$ & & & \\
\hline & $30 \sim 34^{\S}$ & $49.36 \pm 4.61$ & & & \\
\hline & $35 \sim 39^{\prime \prime}$ & $51.29 \pm 5.81$ & & & \\
\hline & $40 \sim 44^{91}$ & $48.84 \pm 5.19$ & & & \\
\hline & $45 \sim 49^{\#}$ & $48.47 \pm 4.07$ & & & \\
\hline & $>50^{\star \star}$ & $45.18 \pm 5.23$ & & & \\
\hline \multirow{5}{*}{ Career length } & $<1$ & $51.20 \pm 4.65$ & 2.220 & 0.068 & \\
\hline & $1 \sim 3$ & $50.86 \pm 3.88$ & & & \\
\hline & $3 \sim 5$ & $52.33 \pm 6.89$ & & & \\
\hline & $5 \sim 10$ & $49.62 \pm 5.41$ & & & \\
\hline & $>10$ & $48.91 \pm 4.91$ & & & \\
\hline \multirow[t]{3}{*}{ Type of work } & Full time $^{\dagger}$ & $49.63 \pm 4.90$ & 3.930 & 0.021 & $\dagger<\neq, \neq>\S$ \\
\hline & 3 shift $^{\ddagger}$ & $55.27 \pm 9.23$ & & & \\
\hline & Other (only night) ${ }^{\S}$ & $49.08 \pm 4.11$ & & & \\
\hline \multirow{5}{*}{$\begin{array}{l}\text { Type of work institution } \\
\text { (No. of beds) }\end{array}$} & $<100$ & $53.64 \pm 15.54$ & 2.376 & 0.054 & \\
\hline & $100 \sim 200$ & $50.30 \pm 5.65$ & & & \\
\hline & General hospital & $48.93 \pm 4.58$ & & & \\
\hline & University hospital & $50.56 \pm 4.95$ & & & \\
\hline & Medical labcenter & $55.58 \pm 0.40$ & & & \\
\hline
\end{tabular}


Table 5. Correlation of subcategory and job stress score $(r(p))$

\begin{tabular}{|c|c|c|c|c|c|c|c|}
\hline Variable & A & B & C & D & E & $\mathrm{F}$ & G \\
\hline Job stress score & 1 & & & & & & \\
\hline Interpersonal relation & $.113(0.119)$ & 1 & & & & & \\
\hline Nutrition & $.017(0.815)$ & $.441^{*}(0.000)$ & 1 & & & & \\
\hline Health responsibility & $.256^{*}(0.000)$ & $.570 *(0.000)$ & $.565^{\star}(0.000)$ & 1 & & & \\
\hline Physical activity & $.136(0.060)$ & $.409 *(0.000)$ & $.416^{*}(0.000)$ & $.479 *(0.000)$ & 1 & & \\
\hline Stress management & $.180^{\S}(0.012)$ & $.665^{*}(0.000)$ & $.458^{*}(0.000)$ & $.609 *(0.000)$ & $.609 *(0.000)$ & 1 & \\
\hline Spiritual growth & $.171^{\S}(0.018)$ & $.711^{*}(0.000)$ & $.507^{*}(0.000)$ & $.553^{*}(0.000)$ & $.422 *(0.000)$ & $.665^{\star}(0.000)$ & 1 \\
\hline
\end{tabular}

${ }^{\star} p<0.01 ;{ }^{\S} p<0.05$.

A, Job stress score; B, Interpersonal relation; C, Nutrition; D, Health responsibility; E, Physical activity; F, Stress management; G, Spiritual growth.

(low-stress group and medium-stress group) $(p<0.001)$. There were significant differences in lack of reward and interpersonal conflict between low-stress group and medium or high-stress group $(p<0.001)$. There was significant difference in job insecurity between low stress group and high stress group $(p<0.001)$. There was significant difference in organization system between low and middle groups than high stress group $(p<0.001)$.

\section{General characteristics of job stress}

Table 4 shows job stress according to general characteristics. The majority factors of general characteristics showed no significance in job stress. However, age and type of work showed significant difference in general characteristics. In particular, age of 35 39 years was significantly different from age of 50 years $(p<0.006)$. Type of work showed significant difference between 3 -shift and full-time or other group (only night) $(p<$ 0.021). No significance of career length and type of work institution.

\section{Correlation of job stress included subcategory}

Six subcategories of job stress showed a significant positive correlation with job stress scores. For job stress, health responsibility, stress management and spiritual growth were significant correlation (Table 5).

\section{DISCUSSION}

This population-based wild study was the first to examine the level of job stress of medical technologist and the developed SF-KOSS instrument using by reported. In addition, we used research tool with high reliability and validity as a job stress tool that can be commonly encountered in workers in Korea, and it reflects the actual situation of medical technologists working environment. Better performance in or higher frequency of health-promoting life-style behaviors might reduce the chances of developing stress-related symptoms. Kim and Kim reported average job stress score of 51.41, with average of top $25 \%$ of the subjects (high level of stress) being 59 and average of subjects low level of stress being 43 , in clinical nurses [7]. Job stress does not affect lower self-efficacy of hospital nurses [8]. In medical care, employees with lower degree of autonomy, self-efficacy and authority to influence job content had highest overall physical exposure levels [9]. Clear work tasks, positive feedback, physically non-strenuous work, self-rated health and leisure time factors were found be important for high work ability [10]. Self-efficacy, personal safety and musculoskeletal well-being were important for medical workers, while work ability of care aides was associated with safety climate and also with non-changeable factors of age and seniority. Proactive workplace interventions need to focus on potentially modifiable factors such as self-efficacy, safety climate, physical job demands and musculoskeletal well-being [11]. In order to settle down clinical trial in the field of laboratory, intervention to relieve stress of person and resolving problems in salary, job description and administration are necessary. Also, professional training programs and human resource systems that improve job satisfaction are needed. Previously, In biomarker with job stress study, 
immune factors related to job stress affected health status variable. Job (dis)satisfaction was related to psychological mechanisms in stress affecting cellular immune function [12]. For correlations between biochemical and immunological variables analyzed by Pearson coefficients, reduction of NK CD57 and IL-6 contents better characterizes occupational satisfaction [13]. Work stress is related to elevated stress responses of HPA (hypothalamus-pituitary-adrenal) axis biomarkers [14]. Urinary IL-8 might be an appropriate biomarker for stress assessment [15]. Therefore, it is necessary to identify the biomarkers and the job stress in medical technologists.

Anxiety and job insecurity (greater than occupational stress) reduce NK cell activity, thus affecting health lifestyle $[16,17]$. The majority of psychological and physical stress indicators result from individual- environment interaction [18]. Generally, both dimensions of job satisfaction and manifestations of occupational stress are relevant predictors of burnout syndrome [19]. As a result of analyzing the factors related to subcategories of job stress, interpersonal relationship, nutrition and physical activity did not affect the total score of job stress, but health responsibility, stress management, spiritual growth showed statistically significant increase. This is thought to be a part of the work environment of the medical technologists, and the factors required for health promoting behaviors impacts. Among job stress factors, only job instability and lack of job autonomy are found to be factors having a significant effect on accidents. However, factors showing significant correlation with cognitive failure turn out to be physical environment, lack of job autonomy, relational conflict, organizational system, improper reward and work culture, which are subcategories of job stress. This suggests that job stress factors can have an indirect effect on accidents through cognitive failure. Thus, future research needs to cover structural equation modeling to examine direct and indirect effects of job stress on accidents using cognitive failure [20]. Previously, Awareness on the part of medical technologists were stress and the harm it can cause. Increased awareness caused by the less stressful working environments and an improved quality of laboratory life for human health [21]. Also, health-related behavior factors, job-related factors and job satisfaction were influenced by significant related variables affecting the level of burnout in medical technologist [22].

This study reveals that job stress are important factors related to medical technologist. Conclusively, the results suggest that it would be necessary to develop various programs to improve health-promoting behavior and job satisfaction. Special role and improper treatment of job stress were correlated with salary, technical level and administrative satisfaction, except for correlation of medical people with job satisfaction. Based on the results of this study, to reduce job stress, to enhance job satisfaction of medical technologist and to solve health conditions and efforts of health, it is necessary to develop and apply plans for administrative support and arbitration programs. Educational programs should be devised to promote healthy lifestyle and also to achieve early detection and appropriate intervention.

\section{요 약}

본 연구는 임상병리사를 대상으로 직무스트레스의 정도를 파악하고, 이들 간의 상관성을 규명함으로써 직무스트레스의 감소를 위해 건강을 높일 수 있는 방안을 마련하는데 기초자료 를 제공하고자 수행한 서술적 조사 연구이다. 임상병리사의 직 무스트레스는 최대 100점에 49.74점으로 나타났고, 하부영역 별로 직무불안정이 64.42점으로 가장 높았고, 조직체계가 52.46점, 보상부적절이 52.30점, 물리적환경이 51.15점, 직무 요구도는 49.57점, 직무자율성결여는 48.43점, 관계갈등은 39.78점 순이었고, 직장문화는 39.77점으로 가장 낮게 나타났 다. 본 연구결과를 통해 임상병리사의 직무스트레스에 관련한 요인들의 상관성을 확인하였고 직무스트레스가 높은 군에서는 직무불안정을 감소시키고 건강증진에서의 신체활동을 증가시 키는 활동이 요구되고, 이를 통해 직무스트레스 감소를 위해 절 실한 프로그램의 개발이 요구되고. 건강상태 인자에 대한 정보 를 향후 조사해야 할 것으로 사료된다.

Acknowledgements: None

Funding: None

Conflict of interest: None 


\section{REFERENCES}

1. Havlovic SJ, Keenan JP. Coping with work stress: The influence of individual differences. In Crandall. R, Perrrewe PL, editoes. Occupational stress. 1st. Washington: Taylor \& Francis; 1995. p179-192.

2. National Institute for Occupational Safety and Health. Stress $\cdots$ At Work [Internet]. Washington: Centers for Disease Control and Prevention; 2014 [cited 2016 February 17]. Available from: http://www.cdc.gov/niosh/docs/99-101.

3. Alpert JS. Physician depression. Am J Med. 2008;121(8):643.

4. Melnyk BM, Hrabe DP, Szalacha LA. Relationships among work stress, job satisfaction, mental health, and healthy lifestyle behaviors in new graduate nurses attending the nurse athlete program: a call to action for nursing leaders. Nurs Adm Q. 2013;37(4):278-285.

5. Kobayashi F, Furui H, Akamatsu Y, Watanabe T, Horibe H. Changes in psychophysiological functions during night shift in nurses. Influence of changing from a full-day to a half-day work shift before night duty. Int Arch Occup Environ Health. 1997;69(2):83-90.

6. Chang S, Koh S, Kang D. Developing an occupational stress scale for Korean employees. Korean J Occup Environ Med. 2005;17(4):297-317.

7. Kim JS. Kim CJ. Association of job stress with health-promoting behaviors and health status in clinical nurses. Korean J Occup Health Nurs. 2016:24(4):311-319.

8. Jung EJ, Do BN. Job stress, self-efficacy and health promoting behaviors in hospital nurses. J Korean Acad Psych Mental Health Nurs. 2002;11(3):398-405.

9. Ford MT, Tetrick LE. Relations among occupational hazards, attitudes, and safety performance. J Occup Health Psychol. 2011;16(1):48-66.

10. Hägglund KM, Helsing C, Sandmark H. Assistant nurses working in care of older people: associations with sustainable work ability. Scand J Caring Sci. 2011;25(2):325-332.

11. Larsson A, Karlqvist L, Westerberg M, Gard G. Identifying work ability promoting factors for home care aides and assistant nurses. BMC Musculoskelet Disord. 2012;13:1.

12. Amati M, Tomasetti M, Ciuccarelli M, Mariotti L, Tarquini LM, Bracci M, et al. Relationship of job satisfaction, psychological distress and stress-related biological parameters among healthy nurses: a longitudinal study. J Occup Health. 2010;52(1):1-8.

13. Amati M, Tomasetti M, Mariotti L, Tarquini LM, Ciuccarelli M, Poiani M, et al. Study of a population exposed to occupational stress: correlation among psychometrics tests and biochemical-immunological parameters. G Ital Med Lav Ergon. 2007;29(3):356-358.

14. Chandola T, Heraclides A, Kumari M. Psychophysiological biomarkers of workplace stressors. Neurosci Biobehav Rev. 2010;35(1):51-57.

15. Fukuda H, Ichinose T, Kusama T, Sakurai R, Anndow K, Akiyoshi N. Stress assessment in acute care department nurses by measuring interleukin-8. Int Nurs Rev. 2008;55(4):407-411.

16. Boscolo PG. Effects of occupational stress and job insecurity on the immune response. Ital Med Lav Ergon. 2009;31(3):277-280.

17. Sung HH, Song CS, Choi KM, Park CE. A study on the relationship between obesity factors and NK cell activity in white-collar females. Korean J Clin Lab Sci. 2016;48:196-201.

18. Fortes-Ferreira L, Peiró JM, González-Morales MG, Martín I. Work-related stress and well-being: the roles of direct action coping and palliative coping. Scand J Psychol. 2006;47(4): 293-302.

19. Ogresta J, Rusac S, Zorec L. Relation between burnout syndrome and job satisfaction among mental health workers. Croat Med J. 2008;49(3):364-374.

20. Park YM, Kim SY. Impacts of job stress and cognitive failure on patient safety incidents among hospital nurses. Saf Health Work. 2013;4(4):210-215.

21. Chang SW, Cho YJ, Kim YJ. An empirical study of job stress for effective human resources management. Korean J Clin Lab Sci. 1988;20(1):260-270.

22. Song YB, Lee TY, Kim YR. Relationships of emotional labor, job satisfaction and burnout among medical technologists in a university hospital. Journal of the Korea Academia-Industrial cooperation Society. 2014;15(8):5140-5149. 